\title{
Androgen replacement therapy in men: current evidence and controversy
}

\author{
Terapia de reposição hormonal no sexo masculino: evidências e controvérsias
}

\author{
João Arthur Brunhara Alves Barbosa ${ }^{1}$, José Cury ${ }^{1}$
}

Barbosa JABA, Cury J. Androgen replacement therapy in men: current evidence and controversy / Terapia de reposição hormonal no sexo masculino: evidências e controvérsias. Rev Med (São Paulo). 2018 May-June;97(3):295-300.

\begin{abstract}
The decline in Testosterone (T) levels in the ageing male - known as andropause or late-onset hypogonadism - may be responsible for several aspects of quality of life decline in older men: erectile dysfunction, impaired libido, decreased strength and energy, sarcopenia, osteopenia, fatigue and even depression in some cases. Many of these signs and symptoms represent the same alterations that are usually attributed to the process of ageing. When some individual presents with such symptoms, hypogonadism should be suspected, and serum $\mathrm{T}$ level should be evaluated. Men who are symptomatic and present low levels of serum Testosterone (generally below 300 $\mathrm{ng} / \mathrm{ml}$ ) are candidates for T replacement therapy. Current evidence shows that, when correctly selected, patients receiving $\mathrm{T}$ replacement may benefit from improvement in libido, erectile function, overall and sexual related quality of life, bone density and muscle mass. Conversely, patients with physiological circulating levels of $\mathrm{T}$ who receive hormone, aiming at supraphysiologic levels, may face severe side effects, including testicular atrophy and behavioral changes. Of note, T replacement, regardless of age and pre-therapy levels, leads to fertility impairment which can be transient or persistent. Direct testosterone replacement should not be indicated in men who wish to conceive children, although other options are available. The effect of Testosterone replacement on prostate cancer and on cardiovascular risk is still controversial; hypogonadal men known to have prostate cancer or high cardiovascular risk should be examined individually to have their risks stratified and mitigated.
\end{abstract}

Keywords: Androgens; Testosterone; Male; Ageing; Hormone replacement therapy.
RESUMO: A queda dos níveis séricos de testosterona em homens de idade avançada - conhecida como andropausa ou hipogonadismo tardio - pode ser responsável por vários aspectos no declínio da qualidade de vida de homens idosos: disfunção erétil, diminuição da libido, redução de força física e energia, sarcopenia, osteopenia, fadiga e até depressão. Muitos de tais sinais e sintomas representam as mesmas alterações habitualmente atribuídas ao processo de envelhecimento. Quando um paciente se apresenta com esses sintomas, deve-se suspeitar do diagnóstico de hipogonadismo, sendo recomendada a dosagem de níveis séricos de testosterona. Homens sintomáticos apresentando níveis séricos de Testosterona total abaixo de $300 \mathrm{ng} / \mathrm{ml}$ são candidatos a terapia de reposição de testosterona. Evidências atuais indicam que, quando selecionados corretamente, pacientes que recebem reposição de testosterona se beneficiam de melhora na libido, na função erétil, em qualidade de vida nos aspectos gerais e nos quesitos ligados à vida sexual, bem como na densidade óssea e no ganho de massa muscular. No entanto, pacientes com níveis fisiológicos de Testosterona que recebem hormônio exógeno, visando atingir níveis supra-fisiológicos, podem enfrentar efeitos colaterais graves tais como atrofia testicular e alterações comportamentais, como agressividade exacerbada. Deve-se notar que a reposição de testosterona, independentemente da idade e de níveis séricos hormonais pré-tratamento, leva a prejuízo na fertilidade masculina, um fenômeno que pode ser transitório ou persistente. Em pacientes que possuem desejo reprodutivo, a reposição direta de testosterona não deve ser indicada, devendo-se levar em consideração outras opções como o citrato de clomifeno, de ação central. O efeito da reposição de testosterona no risco de câncer de próstata e no risco cardiovascular é ainda controverso; homens com hipogonadismo que sabidamente possuem câncer de próstata ou alto risco vascular devem ser examinados individualmente de modo a terem seus riscos estratificados e mitigados.

Descritores: Androgênios; Testosterona; Masculino; Envelhecimento; Terapia de reposição hormonal.

1. Divisao de Urologia, Hospital das Clinicas HCFMUSP, Faculdade de Medicina, Universidade de Sao Paulo, Sao Paulo, SP, BR. ORCID: Barbosa JABA - https://orcid.org/0000-0001-9646-8588; Cury J - https://orcid.org/0000-0002-5743-7946. Email: jbrunhara@ gmail.com; jc_uro@osite.com.br.

Correspondência: João Arthur B. A. Barbosa. Instituto Central, Hospital das Clínicas da Faculdade de Medicina da Universidade de São Paulo, Urologia - $7^{\circ}$ andar. Av. Dr. Enéas de Carvalho Aguiar, 255. Cerqueira César. São Paulo, SP, BR. CEP: 05403-000. 


\section{INTRODUCTION}

Providing higher quality of life to an everageing population is one of the current goals in contemporary Medicine. Maintenance of physical, mental and sexual function are pursued by both patients and practitioners and challenged by several factors in the elderly population. Among these, the decline in Testosterone (T) levels seen in the ageing male - known as andropause, or late-onset hypogonadism - may play a critical role in several domains, from physical to psychological ${ }^{1,2}$. The Hypogonadism in Males Study estimated that up to 39\% of men aged 45 years or older may have hypogonadism ${ }^{3}$. Of note, several symptoms of male hypogonadism have significant overlap with those usually attributed to the process of ageing, including sarcopenia, osteopenia, fatigue, decreased libido and sexual function and mental manifestations such as depression ${ }^{2,4}$. Hence, a thorough evaluation is needed when the diagnosis of hypogonadism is suspected: neither isolated symptoms nor isolated low levels of serum testosterone are sufficient to diagnose this condition. Rather, the concomitant presence of testosterone levels below $3.2 \mathrm{ng}$ per milliliter associated with at least three sexual symptoms define the condition of late-onset male hypogonadism ${ }^{5}$. Accordingly, indication for testosterone replace therapy relies on the presence of typical symptoms together with low serum $\mathrm{T}$ levels ${ }^{6}$. As per the Endocrine Society guidelines, physicians should measure T levels of patients with signs and symptoms such as reduced libido, reduced muscle mass, depressed mood, decreased energy, osteoporosis, gynecomastia, shrinking testes, infertility, poor concentration, sleep disturbances, increased body fat and anemia ${ }^{7}$ (Table 1).

Table 1. Signs and symptoms which should raise suspicion for hypogonadism and elicit hormonal investigation

\begin{tabular}{l|l}
\hline Reduced libido & Erectile Dysfunction \\
\hline Reduced muscle mass & Osteopenia/osteoporosis \\
\hline Increased body fat & Anemia \\
\hline Gynecomastia & Shrinking testes \\
\hline Decreased energy & Fatigue \\
\hline Depressed Mood & Poor concentration \\
\hline Sleep disturbance & Infertility \\
\hline
\end{tabular}

It has been once unclear, however, if symptoms usually associated with hypogonadism could be correctly attributed to the effect of low circulating hormone levels. It has been speculated that sexual inactivity could lead to reduced testicular function and work as a cause and not consequence of this phenomenon ${ }^{6}$. Evidence for this question has arisen from clinical trials of androgen replacement investigating sexual function of hypogonadal men after Testosterone Therapy $(\mathrm{TTh})^{8}$. Likewise, the effect of TTh has been studied on several domains including quality of life, mental health and body mass. In this review, we will outline the current evidence of the effect of Androgen Replacement Therapy (ART) on several aspects of male hypogonadism, along with implications of such treatment on concerning events such as Prostate Cancer (PCa) and cardiovascular risk.

\section{Erectile function}

Several prospective placebo-controlled randomized clinical trials have been conducted in order to investigate the role of TTh on sexual function among hypogonadal men. Although results were not entirely homogeneous between studies, it must be noted that several factors - including definition of hypogonadism, baseline serum $\mathrm{T}$ among participants and presence of comorbidities may influence the outcomes of trials. Overall, as per demonstrated in a several meta-analyses, ART with Testosterone appears to be effective in improving erectile dysfunction, as measured by the International Index of Erectile Function (IIEF), with greater effect in patients with lower baseline $\mathrm{T}$ levels and more modest effect among patients with clinical comorbidities such as diabetes ${ }^{8-11}$. However, when patients receiving TTh include eugonadal men, this therapy does not appear to provide benefit on sexual function ${ }^{12}$.

Allan et al. ${ }^{13}$ showed that Testosterone replacement with a transdermal patch increased libido, yet with no effect of erectile function. Conversely, in a trial performed by Chiang et al. ${ }^{14}$, TTh resulted in erectile function improvement with no changes in libido. In accordance with the latter, Giltay et al. ${ }^{15}$ demonstrated a 3-point improvement in the IIEF scale in hypogonadal men receiving TTh, with the most effective results in patients with lowest baseline $\mathrm{T}$ values. The most recent evidence indicates that, when indicated to men correctly diagnosed with hypogonadism, TTh presents overall positive results on erectile function ${ }^{8}$. However, the improvement on erectile function attributed to TTh alone may be modest. In cases of severe erectile dysfunction, this treatment may not be enough to satisfy an individual's desire for improvement. Likewise, when other factors such as obesity and diabetes are present, vascular and neurogenic mechanisms causing erectile dysfunction are not addressed by TTh. Although ART may be effective in improving erectile function in hypogonadal men, physicians must carefully select patients who may benefit from this therapy and be aware of its limitations.

\section{Quality of life and mental health}

Several randomized controlled trials have been performed to investigate if TTh would lead to Quality of Life (QoL) improvement in hypogonadal men. A 
recent meta-analysis of randomized controlled trials has demonstrated that Testosterone replacement in men with late onset hypogonadism can have significant impact on QoL in several domains including psychological, somatic and sexual aspects ${ }^{16}$. However, individual studies have shown different results in select domains and populations. Legros et al. ${ }^{17}$ randomized 322 subjects for placebo or an oral dose of 80,160 or $240 \mathrm{mg}$ of Testosterone undecanoate in a multicentric study. Improvement in overall QoL was significant but similar between placebo and TTh; conversely, in sexual-related QoL, T replacement with 160 mg showed significant improvement over placebo or other doses. Srinivas-Shankar et al. ${ }^{18}$, in a study with 274 patients randomized for placebo or transdermal $\mathrm{T}$ replacement of $50 \mathrm{mg}$ per day have demonstrated significant improvement in overall, sexual and somatic QoL. Of note, patients who presented most significant improvement were elder and more fragile individuals. Ho et al randomized 120 for placebo or intramuscular testosterone undecanoate injections of $1000 \mathrm{mg}^{19}$. They have found that patients receiving $\mathrm{T}$ injections presented significant improvement on overall QoL, psychological and somatic aspects, with a non-significant improvement in the sexual domain. Taken together, the current evidence accumulated, as analyzed in a meta-analysis, suggests that TTh can in fact lead to QoL improvement in hypogonadal men. Furthermore, it appears that $\mathrm{T}$ replacement in men with late onset hypogonadism may have a beneficial effect on reducing depression and enhancing cognitive performance among symptomatic patients ${ }^{20}$. It must be noted, however, that such effects have only been demonstrated for hypogonadal men with document levels of serum $\mathrm{T}$ below normality.

\section{Sarcopenia and osteoporosis}

The role of T on muscle anabolism is one of the first documented effects of this hormone. The indiscriminate use of exogenous $\mathrm{T}$ in eugonadal men with this purpose often leads to supraphysiologic levels of $\mathrm{T}$ and corresponding adverse effects, including mental and behavioral changes ${ }^{21}$. However, in symptomatic individuals with hypogonadism, TTh is indicated to restore skeletal muscle mass. It has Table 3. Treatment options for hypogonadism

\begin{tabular}{l|l|l}
\hline Formulation & Dose & Potential adverse effects \\
\hline Intramuscular injection & $75-100 \mathrm{mg}$ weekly or 150-200 mg every 2 weeks & \\
\hline Transdermal gel & $\begin{array}{l}5-10 \mathrm{~g} \text { applied daily }(5-10 \mathrm{mg} \text { testosterone } \\
\text { systemically absorbed) }\end{array}$ & Gel transference to partner or children \\
\hline Transdermal patches (non-scrotal) & $2.5-7.5 \mathrm{mg}$ applied nightly & Skin reaction \\
\hline Long-lasting intramuscular injection & $750 \mathrm{mg}$ every 10 weeks & Pulmonary oil microembolization \\
\hline Buccal tablets & $\begin{array}{l}30 \mathrm{mg} \text { tablet applied to the buccal mucosa every } \\
12 \mathrm{~h}\end{array}$ & Inflammation of the gums \\
\hline
\end{tabular}

been consistently demonstrated that $\mathrm{T}$ replacement in hypogonadal men can lead to increased muscle mass, increase in bone density, increased strength and a decrease in fat mass ${ }^{22-24}$.

\section{Diagnosis and treatment}

Patients presenting with symptoms suggestive of hypogonadism, in special older men with a suspicion of late onset hypogonadism, should have their hormonal investigation performed. These symptoms include reduced libido, fatigue, sarcopenia, depressed mood, increased body fat among others (Table 1). The diagnosis of hypogonadism consists in the presence of symptoms associated with serum testosterone below a given cut-off, which may vary from $230 \mathrm{ng} / \mathrm{dl}$ to $300 \mathrm{ng} / \mathrm{dl}$ according to different societies (Table 2). Complementary investigation should also include Follicle stimulating hormone and Luteinizing hormone.

Table 2. Diagnostic reference values for hypogonadism, considering the limit below which patients will usually benefit from testosterone therapy

\begin{tabular}{l|l}
\hline Endocrine Society & $\begin{array}{l}\text { Total testosterone below 280-300 ng/dl } \\
\text { Free testosterone below 5-9 ng/dl } \\
\text { *excluding evaluation during acute or } \\
\text { subacute illness }\end{array}$ \\
\hline $\begin{array}{l}\text { European Association } \\
\text { of Urology, American } \\
\text { Society of Andrology }\end{array}$ & Total testosterone below $230 \mathrm{ng} / \mathrm{dl}$ \\
\hline
\end{tabular}

If symptoms are enough to impair patient's quality of life, and after discussion of potential benefits and adverse effects, testosterone replacement therapy may be offered to patients. Options for testosterone therapy include intramuscular, transdermal or buccal presentations (Table 3). Each method is associated with a different profile of adverse effects and has with a particular posology. Intramuscular injections are associated with relatively few adverse effects, and require injections twice a month. By contrast, a transdermal gel will not require injections, but will demand daily applications and is associated with a risk of transmission of hormone to partners and children. 


\section{Potential adverse effects}

\section{Infertility}

The use of exogenous $\mathrm{T}$ is well known to have negative effects on male fertility. The elevated serum $\mathrm{T}$ resulting from exogenous intake leads to a negative feedback inhibition of the hypothalamic pituitary gonadal axis. Such inhibition results in suppression of spermatogenesis, low intratesticular $\mathrm{T}$ levels and ultimately oligospermia or azoospermia and testicular atrophy ${ }^{25}$. Although this effect can be reversible in up to $50 \%$ of patients after 6 months of therapy cessation, up to $10 \%$ of patients may remain persistently azoospermic after $\mathrm{TTh}^{26}$. Hence, exogenous $T$ replacement must be discouraged in hypogonadal men with intention to conceive in the future. Instead, such patients should be offered alternative treatments aiming at upregulation of the hypothalamic pituitary axis and ultimately elevating endogenous $\mathrm{T}$ production. Among options of such a treatment there is Clomiphene citrate, a selective estrogen receptor modulator, which acts in the hypothalamus and pituitary opposing the inhibitory effect of estrogens on gonadotropin release. As a result, gonadotropin levels rise and $\mathrm{T}$ production by the testes is stimulated ${ }^{27}$. Other options include human Chorionic Gonadotropin (hCG) - which stimulates endogenous $\mathrm{T}$ production by Leydig cells - and aromatase inhibitors, such as anastrozole, which block peripheral conversion of $\mathrm{T}$ to estrogen and are most effective in obese subjects ${ }^{27}$.

\section{Prostate cancer}

Current understanding of the relationship between Testosterone and Prostate Cancer does not follow a linear correlation. Rather, the saturation model proposed by Morgentaler and Traish predicts that changes in serum $T$ concentration below the point of maximal androgenreceptor binding will lead to clinically significant modifications in prostate growth and prostate cancer ${ }^{28}$. This is the case for androgen deprivation therapy, in which levels are aimed at $30 \mathrm{ng} / \mathrm{dL}$ or lower. However, in patients with levels of serum $\mathrm{T}$ above the point of maximal androgen-receptor binding, oscillations of serum $\mathrm{T}$ do not correlate to clinically significant changes in prostate growth or cancer. This theory explains the observation that endogenous levels of T do not increase the risk of Prostate Cancer ${ }^{29,30}$. Current evidence does not show an increased risk for Prostate Cancer in hypogonadal men receiving androgen replacement therapy as compared to age-paired controls or to subjects receiving placebo ${ }^{31,32}$. Furthermore, the previous use of T replacement does not increase Prostate Cancer severity in patients presenting this diagnosis ${ }^{33}$. The use of Testosterone replacement in hypogonadal men with treated prostate cancer may be considered, although this is still a controversial subject ${ }^{34}$. Current evidence suggests that hypogonadal men with low or moderate risk disease receiving T replacement after radical prostatectomy do not present increased risk of disease recurrence ${ }^{35}$. Yet, series of patients receiving $\mathrm{T}$ Therapy after surgery or radiotherapy are small and evidence is limited. Although T therapy may be considered for hypogonadal patients after treatment for Prostate Cancer, it should be restricted to patients with low or moderate risk disease and undetectable or stable Prostate-Specific Antigen (PSA) levels. Patients should be informed that the current level of evidence is insufficient to definitively exclude the risk of disease recurrence, although disease recurrence may or may not be related to this therapy.

\section{Cardiovascular risk}

The potential risks and benefits of $\mathrm{T}$ for cardiovascular effects have long been unknown and controversial. Different studies have elicited opposing results regarding the risk of cardiovascular events following testosterone replacement. A recent systematic review investigated such contrasting results ${ }^{36}$. Morgentaler et al demonstrated that, while 4 studies have shown an increased for cardiovascular events after $\mathrm{T}$ prescription, several dozen studies have shown, conversely, a beneficial effect of normal testosterone levels on cardiac risk and mortality. These authors have demonstrated, according to their review of the literature, that current evidence suggests that serum $\mathrm{T}$ concentration is inversely related to incidence and severity of coronary artery disease, as well as with mortality (level of evidence IIa). Also of note, a recent meta-analysis including 75 randomized controlled trials with over 5,000 patients did not demonstrate an overall increase in cardiovascular risk after $\mathrm{T}$ replacement; furthermore, in patients with metabolic derangements, $\mathrm{T}$ therapy was associated with a protective effect on cardiovascular risk ${ }^{37}$. As per most recent evidence, it appears that testosterone replacement in older men with hypogonadism could provide cardiovascular protection and carries a lower risk for cardiovascular events $^{38}$. In a retrospective cohort including over 40,000 men, Cheetham et al. ${ }^{38}$ showed that hypogonadal men who received testosterone presented lower risk of stroke and myocardial infarction as compared to those who never received $\mathrm{T}$ reposition. However, this effect may be significant only when hormone levels reach normality. It appears that $\mathrm{T}$ replacement could potentially provide cardiovascular benefit for selected patients; however, this statement is yet to be confirmed. Currently, evidence for the use of T in men at high cardiovascular risk is not considered to be enough to safely indicate hormone reposition in such patients ${ }^{38}$. Men at low or intermediate risk are considered safe candidates for T therapy; however, this should not be indicated in men with a recent myocardial infarction, revascularization, poorly controlled heart failure, and stroke within the previous 6 months ${ }^{39}$.

\section{CONCLUSIONS}

Testosterone replacement in hypogonadal men 
can lead to several benefits, including recovery of sexual function, libido, muscle mass and overall quality of life. However, diagnosis of this condition and indication for therapy must be strict and follow guidelines. The use of Testosterone in asymptomatic men or in subjects with normal levels of serum Testosterone should not be encouraged by physicians.

\section{REFERENCES}

1. Myers JB, Meacham RB. Androgen replacement therapy in the aging male. Rev Urol. 2003;5(4):216-6. Available from: https://www.ncbi.nlm.nih.gov/pmc/articles/PMC1508369/.

2. Khera M, Adaikan G, Buvat J, et al. Diagnosis and treatment of testosterone deficiency: recommendations from the Fourth International Consultation for Sexual Medicine (ICSM 2015). J Sex Med. 2016;13:1787-804. doi: 10.1016/j. jsxm.2016.10.009.

3. Mulligan T, Frick MF, Zuraw QC, et al. Prevalence of hypogonadism in males aged at least 45 years: the HIM study. Int J Clin Pract. 2006;60:762-9. doi: 10.1111/j.17421241.2006.00992.x.

4. Buvat J, Maggi M, Guay A, Torres LO. Testosterone deficiency in men: systematic review and standard operating procedures for diagnosis and treatment. J Sex Med. 2013;10:245-84.

5. Wu FC, Tajar A, Beynon JM, et al. Identification of late-onset hypogonadism in middle-aged and elderly men. N Engl J Med. 2010;363(2):123-35.

6. Yeap BB, Grossmann M, McLachlan RI, et al. Endocrine Society of Australia position statement on male hypogonadism (part 2): treatment and therapeutic considerations. Med J Aust. 2016;205:228-31. doi: 10.5694/mja16.00448.

7. Bhasin S, Cunningham GR, Hayes FJ, Matsumoto AM, Snyder PJ, Swerdloff RS, Montori VM; Task Force, Endocrine Society. Testosterone therapy in men with androgen deficiency syndromes: an Endocrine Society clinical practice guideline. J Clin Endocrinol Metab. 2010;95(6):2536-59. doi: 10.1210/ jc.2009-2354.

8. Corona G, Rastrelli G, Morgentaler A, et al. Meta-analysis of results of testosterone therapy on sexual function based on International Index of Erectile Function Scores. Eur Urol. 2017;72(6):1000-11.

9. Jain P, Rademaker AW, McVary KT. Testosterone supplementation for erectile dysfunction: results of a metaanalysis. J Urol. 2000;164:371-5. https://doi.org/10.1016/ S0022-5347(05)67363-6.

10. Isidori AM, Giannetta E, Gianfrilli D, et al. Effects of testosterone on sexual function in men: results of a metaanalysis. Clin Endocrinol (Oxf). 2005;63:381-94. doi: 10.1111/j.1365-2265.2005.02350.x.

11. Boloña ER, Uraga MV, Haddad RM, et al. Testosterone use in men with sexual dysfunction: a systematic review and metaanalysis of randomized placebo-controlled trials. Mayo Clin
Proc. 2007;82:20-8. doi: 10.4065/82.1.20.

12. Huo S, Scialli AR, McGarvey S, et al. Treatment of men for "low testosterone": a systematic review. PLoS One. 2016;11:e0162480. doi: 10.1371/journal.pone.0162480.

13. Allan CA, Forbes EA, Strauss, BJ, McLachlan RI. Testosterone therapy increases sexual desire in ageing men with low-normal testosterone levels and symptoms of androgen deficiency. Int J Impot Res. 2008;20:396-401.

14. Chiang HS, Cho SL, Lin YC, Hwang TI. Testosterone gel monotherapy improves sexual function of hypogonadal men mainly through restoring erection: evaluation by IIEF score. Urology. 2009;73:762-6.

15. Giltay EJ, Tishova YA, Mskhalaya GJ, Gooren LJ, Saad F, Kalinchenko SY. Effects of testosterone supplementation on depressive symptoms and sexual dysfunction in hypogonadal men with the metabolic syndrome. J Sex Med. 2010;7:257282. doi: 10.1111/j.1743-6109.2010.01859.x.

16. Nian Y, Ding M, Hu S, et al. Testosterone replacement therapy improves health-related quality of life for patients with late-onset hypogonadism: a meta-analysis of randomized controlled trials. Andrologia. 2017;49:e12630. doi: 10.1111/ and. 12630 .

17. Legros JJ, Meuleman EJ, Elbers JM, Geurts TB, Kaspers MJ, Bouloux PM. Oral testosterone replacement in symptomatic late-onset hypogonadism: effects on rating scales and general safety in a randomized, placebo-controlled study. Eur J Endocrinol. 2009;160:821-31. doi: 10.1530/EJE-08-0634.

18. Srinivas-Shankar U, Roberts SA, Connolly MJ, O'Connell MD, Adams JE, Oldham JA, Wu FC. Effects of testosterone on muscle strength, physical function, body composition, and quality of life in intermediate-frail and frail elderly men: A randomized, double-blind, placebo-controlled study. J Clin Endocrinol Metabol. 2010;95:639-50. doi: 10.1210/ jc.2009-1251.

19. Ho CC, Tong SF, Low WY, Ng CJ, Khoo EM, Lee VK, Tan HM. A randomized, double-blind, placebo-controlled trial on the effect of long-acting testosterone treatment as assessed by the Aging Male Symptoms scale. BJU Int. 2010;110:260-5. doi: 10.1111/j.1464-410X.2011.10755.x.

20. Jung HJ, Shin HS. Effect of Testosterone replacement therapy on cognitive performance and depression in men with testosterone deficiency syndrome. World J Men's Health. 2016;34(3):194-9. doi: 10.5534/wjmh.2016.34.3.194.

21. Bhasin S, Storer TW, Berman N, et al. The effects of supraphysiologic doses of testosterone on muscle size and strength in normal men. N Engl J Med. 1996;335:1-7. doi: 10.1056/NEJM199607043350101.

22. Katznelson L, Finkelstein JS, Schoenfeld DA, et al. Increase in bone density and lean body mass during testosterone administration in men with aquired hypogonadism. J Clin Endocrinol Metab. 1996;81:4358-65. doi: 10.1210/ jcem.81.12.8954042.

23. Snyder PJ, Peachey H, Berlin JA, et al. Effects of testosterone replacement in hypogonadal men. J Clin Endocrinol Metab. 
Barbosa JABA, Cury J. Androgen replacement therapy in men: current evidence and controversy.

2000;85:2670-7. doi: 10.1210/jcem.85.8.6731.

24. Brodsky IG, Balagopal P, Nair KS. Effects of testosterone replacement on muscle mass and muscle protein synthesis in hypogonadal men - a clinical research center study. J Clin Endocrinol Metab. 1996;81:3469-75. doi: 10.1210/ jcem.81.10.8855787.

25. McLachlan RI, O’Donnell L, Meachem SJ, et al. Hormonal regulation of spermatogenesis in primates and man: insights for development of the male hormonal contraceptive. J Androl. 2002;23:149-62. https://doi.org/10.1002/j.1939-4640.2002. tb02607.x.

26. Gu Y, Liang X, Wu W, et al. Multicenter contraceptive efficacy trial of injectable testosterone undecanoate in Chinese men. J Clin Endocrinol Metab. 2009;94:1910-5. doi: 10.1210/ jc.2008-1846.

27. Majzoub A, Sabanegh E. Testosterone replacement in the infertile man. Translat Androl Urology. 2016;5(6):859-65. Doi: 10.21037/tau.2016.08.03.

28. Morgentaler A, Traish AM. Shifting the paradigm of testosterone and prostate cancer: the saturation model and the limits of androgen-dependent growth. Eur Urol. 2009;55:31021. doi: 10.1016/j.eururo.2008.09.024.

29. Khera M, Crawford D, Morales A, Salonia A, Morgentaler A. A new era of testosterone and prostate cancer: From physiology to clinical implications. Eur Urol. 2014;65:11523. doi: 10.1016/j.eururo.2013.08.015.

30. Roddam AW, Allen NE, Appleby P, Key TJ. Endogenous sex hormones and prostate cancer: a collaborative analysis of 18 prospective studies. J Natl Cancer Inst. 2008;100:170-83. doi: 10.1093/jnci/djm323.

31. Shabsigh R, Crawford ED, Nehra A, Slawin KM. Testosterone therapy in hypogonadal men and potential prostate cancer risk: a systematic review. Int J Impot Res. 2009;21:9-23. doi: 10.1038/ijir.2008.31.
32. Feneley MR, Carruthers M. Is testosterone treatment good for the prostate? Study of safety during long-term treatment. J Sex Med. 2012;9:2138-49. doi: 10.1111/j.17436109.2012.02808.x.

33. Kaplan AL, Hu JC. Use of testosterone replacement therapy in the United States and its effect on subsequent prostate cancer outcomes. Urology. 2013;82:321-6.

34. Kaplan AL, Hu JC, Morgentaler A, Mulhall JP, Schulman $\mathrm{CC}$, Montorsi F. Testosterone therapy in men with prostate cancer. Eur Urol. 2016;69(5):894-903. doi: 10.1016/j. eururo.2015.12.005

35. Khera M, Grober ED, Najari B, et al. Testosterone replacement therapy following radical prostatectomy. J Sex Med. 2009; 6: 1165-70. doi: 10.1111/j.1743-6109.2009.01161.x.

36. Morgentaler A, Miner MM, Caliber M, Guay AT, Khera M, Traish AM. Testosterone therapy and cardiovascular risk: advances and controversies. Mayo Clin Proc. 2015;90(2):22451. doi: 10.1016/j.mayocp.2014.10.011.

37. Corona G, Maseroli E, Rastrelli G, et al. Cardiovascular risk associated with testosterone-boosting medications: a systematic review and meta-analysis. Expert Opin Drug Saf. 2014;13(10):1327-51. doi: 10.1517/14740338.2014.950653.

38. Cheetham TC, An J, Jacobsen SJ, Niu F, Sidney S, Quesenberry CP, VanDenEeden SK. Association of testosterone replacement with cardiovascular outcomes among men with androgen deficiency. JAMA Intern Med. 2017;177(4):491-9. doi: 10.1001/jamainternmed.2016.9546.

39. Kloner RA, Carson C, Dobs A, Kopecky S, Mohler ER III. Testosterone and cardiovascular disease. J Am Coll Cardiol. 2016;67:545-57. doi: 10.1016/j.jacc.2015.12.005.

Submitted for publication: Apr 29, 2018

Accepted in: May 17, 2018 